\title{
CONSILIUM
}

Berkala Kajian Konseling Dan Ilmu Keagamaan

Avalaible at http://jurnal.uinsu.ac.id/index.php/consilium

ISSN : 2338-0608 (Print) | ISSN : 2654-878X (Online)

\section{Gambaran Sense of Belonging Mahasiwa Program Studi Bimbingan dan Konseling Islam Fakultas Ushuluddin Adab dan Dakwah IAIN Langsa}

\author{
Latifah, Rizky Andana Pohan, Muhammad Nasir \\ Institut Agama Islam Negeri Langsa, Aceh, Indonesia. \\ Korespondensi: latifahnst2303@gmail.com
}

\begin{abstract}
The background of this study was carried out because of the sustainability of the sense of ownership they have. This can be seen in their participation in participating in activities that support study programs, requesting facilities provided and so on. There are those who take it and do it happily, some are based on an invitation. However, not all students do so in the background because they have a high and low level of ownership, choosing there are a number of things underlying this, thus encouraging the diversity of their possessions. In this study, researchers used a quantitative descriptive research method conducted on BKI Study Program students as respondents with a scale measurement technique using a Likert scale. The results showed that BKI Study Program students have diversity in the sense of belonging. However, in total with an average score of 68.21, it shows that BKI Study Program students have a high level of belonging.
\end{abstract}

Keywords: Sense of belonging; BKI; Department; Students.

\begin{abstract}
Abstrak: Hal ini dikarena terdapat perbedaan alasan mereka dalam mengikuti kegiatan yang menunjang prodi, menjaga fasilitas yang diberikan dan sebagainya. Tujuan dilakukannya penelitian ini adalah untuk mengetahui gambaran sense of belonging pada mahasiswa Program Studi Bimbingan dan Konseling Islam Fakultas Ushuluddin Adab dan Dakwah IAIN Langsa.Peneliti menggunakan pendekatan metode penelitian kuantitatif deskriptifyang di lakukan kepada mahasiswa Prodi BKI sebanyak 63 orang dengan teknik skala pengukuran menggunakan skala dan berdasarkan teori Belongingness yang digunakan oleh Roy Baumeister dan Mark LearyHasil penelitian menunjukkan bahwa mahasiswa Prodi BKI memiliki keberagaman dalam sense of belonging. Namun secara keseluruhan dengan nilai rata-rata yang diperoleh sebesar 68,21 menunjukkan bahwa mahasiswa Prodi BKI memiliki tingkat sense of belonging yang tinggi.
\end{abstract}

Kata kunci: Sense of belonging; BKI; Program Study; Mahasiswa. 


\section{PENDAHULUAN}

حense of belonging atau rasa memliki pada suatu tempat merupakan perasaan - cinta terhadap tempat tersebut sehingga seseorang merasa ikut memiliki tempat tersebut. Perasaan ini kemudian dengan sendirinya akan memunculkan rasa memiliki tanggung jawab yang kuat akan tempat dimana mereka menetap. Sense of belonging akan memacu seseorang untuk melakukan sesuatu dengan sungguh sungguh dalam mencapai tujuan bersama. Rasa memiliki (sense of belonging) dalam diri manusia terlihat dari perasaan aman, nyaman, dikenali dan diterima dalam satu kelompok sama halnya seperti ikan dalam air. Tentunya sense of belonging ini berperan besar terhadap kesehatan mental dan secara tidak langsung kesehatan fisik.

Menurut Jeffery Siauw sense of belonging atau rasa memiliki adalah perasaan seseorang ketika ia merasa dirinya diterima dan di akui sebagai bagian dari suatu komunitas hidup.Sense of belonging biasanya diartikan sebagai rasa memiliki suatu kelompok atau organisasi dalam diri anggotanya. Tentu sense of belonging adalah salah satu kebutuhan dasar untuk manusia. Tidak hanya itu bahwa sense of belonging juga sebagai pembentuk identitas dalam diri individu dan sebagai motivasi untuk berpartisipasi dalam kelompok apapun.

Manusia memang memiiki perasaan ingin diterima. Ini adalah suatu hal yang wajar. Kebutuhan akan penerimaan itu berlaku dimana saja, termasuk di dalam organsasi. Organisasi selalu memiliki sistemnya sendiri, sehingga ketika pertama kali masuk. Seseorang akan dipaksa untuk beradaptasi. Ketika proses beradaptasi ini berjalan. Rasa memiliki terhadap organisasi pun mulai tumbuh.Tumbuhnya sense of belonging tidak dapat berdiri sendiri. Organisasi juga harus memfasilitasi hal tersebut, secara tidak langsung ia mulai merasa menjadi bagian didalamnya. Lalu ia akan melihat kondisi sekitar dan mencari cara untuk bisa diterima. Usaha yang dilakukan orang yang apabila dihargai, akan menimbulkan rasa sedih dan empati pada organisasi dan orang yang didalamnya. Sehingga terbentuklah sense of belonging dalam dirinya. Sense of belonging dalam diri anggota akan memberi dampak positif pada kehidupan organisasi, ia dijadikan sebagai motor untuk kreativitas dan profesionalitas kerja anggota organisasi. Karena rasa memiliki akan menumbuhkan etos kerja yang tinggi, profesional dan optimal. Tentu akan berlaku hal sebaliknya jika dalam organisasi tidak memiliki sense of belonging maka akan timbul perasaan dikhianati ketika usaha dari individu tidak diakui. Sehingga terbentuklah perasaan tidak nyaman yang bila dibiarkan akan menjadi wabah penyakit yang merusak sistem organisasi itu sendiri.

Sense of belonging bisa diwujudkan dalam bentuk inisiatif, keberanian mengambil tanggung jawab dan risiko, serta keinginan berbagi. Dengan Sense of belonging seorang anggota akan senantiasa me mberikan yang terbaik untuk 
organisasinya. Rasa memiliki merupakan ekspresi jiwa yang penting dalam kehidupan seseorang. Rasa memiliki juga akan memiliki dampak yang nyata terlihat dalam perilaku seseorang. Seseorang yang memiliki rasa memiliki akan bertindak peduli, terikat, memiliki empati, termotivasi bahkan mampu memberdayakan dirinya sendiri meskipun tidak ada stimulan.

Rasa memiliki atau sense of belonging disadari ataupun tidak memberikan pengaruh kepada sikap seseorang. Orang yang merasa memiliki terhadap sesuatu akan berbeda dengan orang yang tidak merasa memiliki sesuatu. Contoh ringan saja, orang yang merasa memiliki sebuah rumah, pastinya akan menjaga, merawat serta berusaha agar rumah tersebut tetap rapi, bersih dan nyaman. Namun, berbeda halnya dengan orang yang tidak merasa memiliki rumah itu, mungkin dia akan menelantarkannya dan membiarkannya kotor tak terpelihara. Contoh diatas menggambarkan betapa pentingnya rasa memiliki untuk menentukan sikap seseorang. Rasa memiliki akan melahirkan rasa peduli, perhatian, kasih sayang, dan penjagaan. Sebaliknya ketiadaannya akan memunculkan sikap acuh tak acuh, abai dan penelantaran. Namun ada hal yang tidak boleh luput dari perhatian kita, yaitu rasa memiliki tersebut haruslah sesuai dengan aturan Allah SWT.

Firman Allah Swt dalam Al- Qur'an Surat Maryam ayat 96 secara tidak langsung menjelaskan tentang pentingnya sense of belonging :

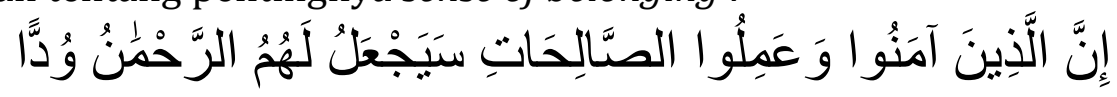

Artinya : Sesungguhnya orang-orang yang beriman dan beramal saleh, kelak Allah Yang Maha Pemurah akan menanamkan dalam (hati) mereka rasa kasih sayang. ( Q.S. Maryam: 19) (Departemen Agama Republik Indonesia, 1989).

Berdasarkan tafsir Jalaluddin al-Mahalli \& Jalaluddin as-Suyuthi ayat diatas mengandung makna bahwa sesungguhnya orang-orang yang beriman dan beramal saleh, kelak Allah Yang Maha Pemurah akan menanamkan dalam hati mereka rasa kasih sayang di antara sesama mereka, mereka saling kasih-mengasihi dan sayangmenyayangi dan Allah SWT mencintai mereka semuanya. Sedangkan menurut tafsir Al-Muyassar ayat diatas mengandung makna bahwa sesungguhnya orangorang yag beriman kepada Allah dan mengikuti Rasul-rasul-Nya serta mengerjakan amal-amal shalih sesuai dengan syariat-Nya, niscaya Allah Yang Maha Pemurah akan memasukkan cinta dan kasih terhadap mereka dalam hati para hamba-Nya.

Kedua tafsir di atas sama-sama menyatakan bahwa orang-orang yang beriman dan beramal shaleh serta mengikuti rasulullah SAW merupakan orangorang yang memiliki rasa kasih sayang di dalam hatinya. Secara tidak langsung, sebagai umat nabi Muhammad SAW yang meyakini bahwa Allah SWT adalah satusatunya tuhan yang berhak di sembah maka hendaknya senantiasa beriman serta memiliki rasa kasih sayang di dalam hatinya dan itu bisa di tumbuhkan apabila terdapat rasa memiliki atau sense of belonging pada dirinya. 
Untuk menumbuhkan sense of belonging pada diri seseorang, sebelum masuk pada suatu tempat atau organisasi, terlebih dahulu harus tahu tujuan dan maksud dari tempat atau organisasi yang akan di masuki, apabila hal tersebut sudah diketahui secara mendalam maka selanjutnya hal yang paling penting adalah niat ikhlas untuk bergabung dalam tempat atau organisasi tersebut dan menjalankan amanat yang emban. Ketika sense of belonging sudah di miliki dalam tempat atau organisasi yang di masuki, maka sikap profesional akan tumbuh dalam melaksanakan dan mengemban amanat tugas yang akan dijalankan. Rasa profesional mutlak perlu untuk ditunjukkan karena hal itu akan mencerminkan keseriusan pada tempat atau organisasi tersebut. Rasa profesionalitas akan timbul seiring dengan rasa memiliki terhadap organisasi yang di tempati. Ketika sense of belonging sudah mulai tumbuh dan rasa profesionalitas sudah tumbuh maka dalam tujuan akan di capai dengan lebih mudah

Berdasarkan penelitian terdahulu mengenai perbedaan sense of belonging berdasarkan suku, ditemukan adanya perbedaan sense of belonging namun tidak begitu signifikan. Hasil ini juga sesuai dengan penelitian mahasiswa UIN Sunan Gunung Jati Bandung tentang pengaruh sense of belonging terhadap komitmen berorganisasi yang menghasilkan pernyataan bahwa sense of belonging berkontribusi dalam mempengaruhi komitmen berorganisasi. Penelitian Huda Saifullah Kamalie dari Universitas Muhammadiyah Malang dalam penelitiannya tentang pengaruh sense of belonging terhadap kualitas hidup lansiamenunjukkan hasil bahwa adanya pengaruh positif sense of belonging terhadap kualitas hidup lansia. Penelitian oleh Sungjun Won tentang sense of belonging dan pembelajaran memberikan hasil bahwa sense of belonging terhadap kelompok sebaya adalah prediktor signifikan dari strategi pembelajaran. ${ }^{1}$ Hasil penelitian yang dilakukan oleh Elisabeth L De Moor tentang Social inhibition, sense of belonging and vulnerability to internalizing problems menyatakan bahwa adanya hambatan sosial terkait dengan sense of belonging yang rendah dan masalah internalisasi. Dari beberapa hasil penelitian yang telah di jelaskan menunjukkan bahwa secara tidak langsung terdapat keberagaman sense of belonging yang dimiliki setiap orang. Hal ini yang menjadi sesuatu yang menarik untuk dilakukannya penelitian mengenai gambaran sense of belonging terkhusus pada mahasiswa Program Studi Bimbingan dan Konseling Islam yang selanjutnya disingkat menjadi prodi BKI.

Dari data yang di dapat oleh peneliti mengenai jumlah keseluruhan mahasiwa Prodi BKI pada tahun 2020 yang berasal dari semester II, IV dan VI adalah sebanyak 171 mahasiswa. Terdapat keberagaman dalam tingkat sense of belonging yang mereka miliki. Hal ini diduga berdasarkan pada yang terlihat seperti keikutsertaan mereka dalam mengikuti kegiatan yang menunjang Prodi misalnya 
pada kegiatan Seminar Nasional, Bakti Konseling Masyarakat, mengklik jurnal Prodi BKI serta dalam menjaga fasilitas yang diberikan dan sebagainya. Ada yang mengikuti dan melakukannya dengan senang hati, ada juga yang berdasarkan ajakan teman maupun dosen dan ada yang tidak mau mengikuti dan melakukannya karena memang tidak menyukainya.Hal ini yang menjadi bukti bahwa sense of belonging yang mahasiswa Prodi BKI miliki beragam. Berdasarkan hal tersebut peneliti tertarik untuk melakukan penelitian mengenai gambaran sense of belonging mahasiswa Prodi BKI yang hasilnya diharapkan mampu memberikan bukti nyata berdasarkan data yang ada dan diukur sesuai dengan alat ukur dan teori yang tepat.

\section{METODE PENELITIAN}

Penelitian ini menggunakan pendekatan kuantitatif dengan jenis pendekatan deskriptif yang memiliki tujuan untuk mendeskripksikan atau menggambarkan fenomena sense of belonging yang dimilki mahahsiswa prodi BKI yang dilakukan menggiunakan angka yang menggambarkan keberagaman sense of belonging yang dimilki mahaiswa prodi BKI. Yang menjadi subjek dalam penelitian ini adalah mahasiswa program studi BKI baik laki-laki maupun perempuan yang berasal dari semester II. IV dan VI. Pengambilan sampel dalam penelitian ini adalah probability sampling dengan teknik proportionate stratified random sampling. Alasan peneliti menggunakan proportionate stratified random sampling dikarenakan teknik ini digunakan pada populasi yang mempunyai susunan bertingkat (strata) atau berlapis serta populasi mempunyai anggota (unsur) yang tidak homogen dan berstrata secara proporsional.

Populasi yang didapatkan berdasarkan mahasiswa yang berasal dari semester II, IV dan VI adalah sebanyak 171 mahasiswa ddan berdasarkan teknik pengambilan sampel yang telah dilakukan sampel yang dihasilkan sebanyak 63 mahasiswa. Teknik pengumpulan data yang digunakan adalah angket atau kuesioner yang dirancang sendiri oleh peneliti berdasarkan indikator dan teori belonginggness oleh roy baumaester dan mark leary dari variabel sense of belonging. Setelah melewati uji validitas dan reliabilitas, jumlah pernyataan dalam angket yang telah dibuat oleh peneliti berjumlah 19 item pernyataan.

\section{HASIL PENELITIAN DAN PEMBAHASAN}


Dalam melakukan penelitian tentu menggunakan responden. Berikut ini adalah karakteristik responden yang digunakan dalam penelitian ini :

Tabel 1. Demografi Sampel Penelitian

\begin{tabular}{ccc}
\hline \multicolumn{2}{c}{ Jenis karakteristik } & Jumlah \\
\hline \multirow{2}{*}{ Semester } & II & $43 \%$ \\
& IV & $37 \%$ \\
\multirow{3}{*}{ Jenis Kelamin } & VI & $21 \%$ \\
& Laki-laki & $14 \%$ \\
Suku & Perempuan & $86 \%$ \\
& Aceh & $52 \%$ \\
& Non Aceh & $48 \%$ \\
\hline
\end{tabular}

Berikut adalah hasil penelitian mengenai gambaran sense of belonging mahaiswa prodi BKI berdasarkan indikator :

Tabel 2. Distribusi frekuensi dan persentase sense of belonging berdasarkan kategori $(n=63)$

\begin{tabular}{cccc}
\hline Interval Skor & Kategori & F & \% \\
\hline $77-95$ & Sangat Tinggi & 7 & 11,11 \\
$64-76,5$ & Tinggi & 40 & 63,49 \\
$51-63,5$ & Sedang & 16 & 25,40 \\
$38-50,5$ & Rendah & 0 & 0,00 \\
$19-37,5$ & Sangat Rendah & 0 & 0,00 \\
Total & & 63 & 100,00 \\
\hline
\end{tabular}

Tabel di atas memperlihatkan bahwa sebagian besar mahasiswa memiliki sense of belonging yang tinggi yaitu sebesar 63.49\%, sebagian lainnya mahasiswa lainnya berada pada kategori sangat tinggi yaitu sebesar $11.11 \%$, kemudian pada kategori sedang sebesar $25.40 \%$. Untuk lebih rincinya dapat dilihat pada tabel di bawah ini.

Tabel 3. Deskripsi Rata-rata ( Mean) dan Persentase (\%) sense ofbelonging berdasarkan indikator

\begin{tabular}{|c|c|c|c|c|c|c|c|c|c|}
\hline \multirow{2}{*}{ No } & \multicolumn{9}{|c|}{ SKOR } \\
\hline & Indikator & Ideal & Max & Min & $\Sigma$ & Mean & $\%$ & SD & Ket \\
\hline 1 & $\begin{array}{l}\text { Motivasi yang } \\
\text { mendasar pada } \\
\text { manusia ( } 4 \text { ) }\end{array}$ & 20 & 18 & 11 & 919 & 14,59 & 72,94 & 1,80 & $\mathrm{~T}$ \\
\hline 2 & $\begin{array}{l}\text { Hubungan } \\
\text { Interpersonal Yang } \\
\text { Kuat Dan Stabil Serta }\end{array}$ & 20 & 20 & 8 & 925 & 14,68 & 73,41 & 2,76 & $\mathrm{~T}$ \\
\hline
\end{tabular}




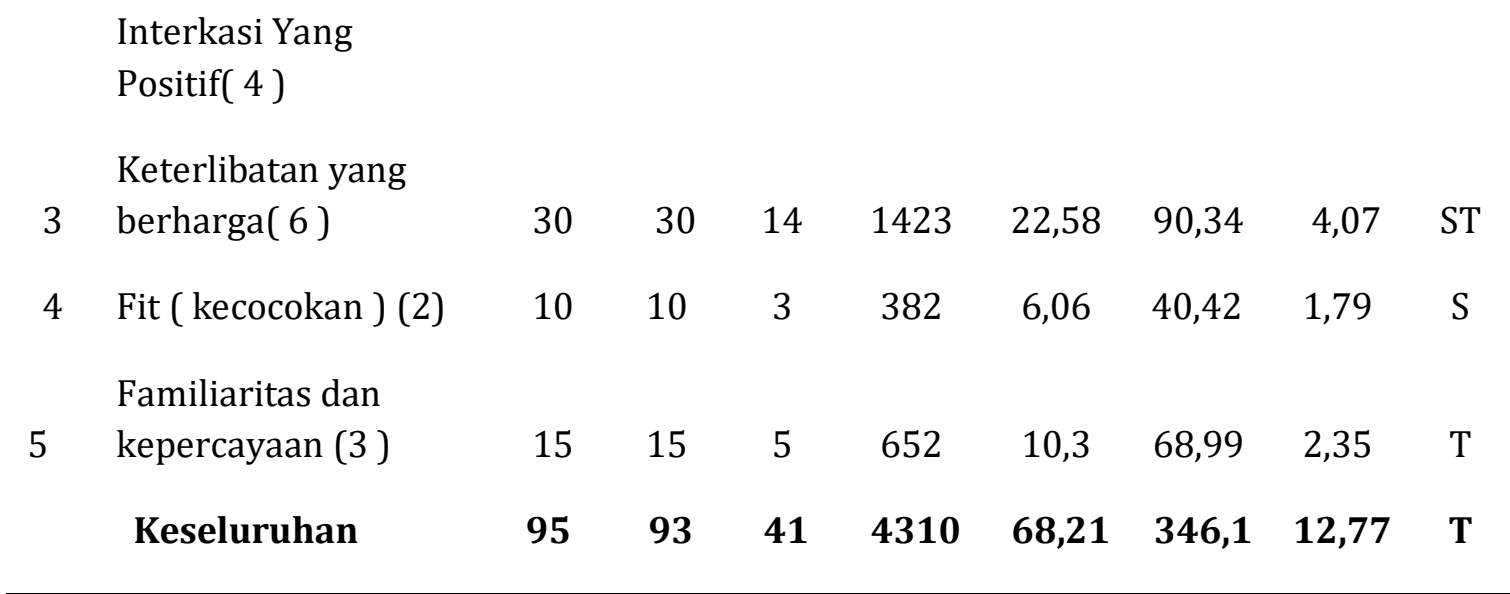

Tabel diatas memperlihatkan bahwa secara rata-rata dari keseluruhan indikator, mahasiswa memiliki sense of belonging yang tinggi terhadap program studi bimbingan dan konseling islam yaitu sebesar 68,21. Hal ini dapat dilihat dari hasil analisi data pada masing-masing indikator, antara lain motivasi yang mendasar pada manusia yaitu sebesar 14,59, hubungan interpersonal yang kuat dan stabil serta interkasi yang positif yaitu sebesar 14,68 Keterlibatan yang berharga yaitu sebesar 22,58, Fit (kecocokan) yaitu sebesar 6,06 dan familiaritas dan kepercayaan yaitu sebesar 10,3.

\section{Motivasi yang mendasar pada manusia}

Hasil analisis data penelitian menunjukkan bahwa secara rata-rata keseluruhan dari indikator motivasi yang mendasar pada mahasiswa Prodi BKI berada dalam kategori tinggi. Hal ini berarti motivasi yang dimiliki mahasiwa Prodi BKI sudah baik. Motivasi yang dimaksud adalah sesuatu alasan yang mendorong seseorang untuk melakukan, menyelesaikan, menghentikan dan sebagainya suatu aktivitas untuk mencapai tujuan tertentu yang diinginkan dari motivasi tersebut. Berdasarkan teori hierarki kebutuhan Abraham Maslow, teori X dan teori Y Douglas McGregor maupun teori motivasi kontemporer, arti motivasi adalah alasan yang mendasari sebuah perbuatan yang dilakukan oleh seorang individu. Seseorang dikatakan memiliki motivasi tinggi dapat diartikan orang tersebut memiliki alasan yang sangat kuat untuk mencapai apa yang diinginkannya dengan mengerjakan apa yang dilakukannya sekarang.

Hal ini juga terlihat semakin banyak mahasiswa yang tertarik terhadap Prodi BKI sehingga dapat disimpulkan bahwa motivasi yang dimiliki cukup tinggi yang nantinya akan membuat mahasiswa tersebut semakin meningkatkan sense ofbelonging yang telah dimiliki. Pernyataan-pernyataan yang menggambarkan motivasi yang mendasar pada manusia terlihat pada item nomor 1, 2, 3 dan 4 pada kuesioner yang telah di uji pada mahasiswa Prodi BKI. 


\section{Hubungan interpersonal yang kuat dan stabil serta interkasi yang positif}

Hasil analisis data penelitian menunjukkan bahwa secara rata-rata keseluruhan dari indikator hubungan interpersonal yang kuat dan stabil serta interkasi yang positif mahasiswa Prodi BKI juga berada dalam kategori tinggi. Hal ini berarti hubungan interpersonal yang kuat dan stabil serta interkasi yang positif yang dimiliki mahasiwa Prodi BKI sudah baik.

Menurut Roger hubungan interpersonal yang kuat dan stabil serta interkasi yang positif dapat terjadi secara efektif apabila memenuhi kondisi sebagai berikut: 1) Bertemu satu sama lain secara personal. Hubungan interpersonal ditandai dengan adanya intensitas tatap muka dan bertemu secara langsung, 2) Empati secara tepat terhadap pribadi yang lain dan berkomunikasi yang dapat dipahami satu sama lain secara berarti. Empati terkait dengan kemampuan untuk merasakan apa yang dialami oleh orang lain serta kemampuan dalam menempatkan diri dalam kesulitan yang dialami, 3) Menghargai satu sama lain, bersifat positif dan wajar tanpa menilai atau keberatan. Terjalinnya hubungan interpersonal yang efektif antara satu sama lain terlihat dari adanya kesediaan untuk menghargai gagasan yang diutarakan, 4) Menghayati pengalaman satu sama lain dengan sungguhsungguh, bersikap menerima dan empati satu sama lain, 5) Merasa bahwa saling menjaga keterbukaan dan iklim yang mendukung dan mengurangi kecenderungan gangguan arti, 6) Memperhatikan tingkah laku yang percaya penuh dan memperkuat perasaan aman terhadap yang lain.

Dengan demikian keenam kondisi diatas sudah dilakukan oleh mahasiswa Prodi BKI. Hal ini telah terbukti dengan indikator hubungan interpersonal yang kuat dan stabil serta interkasi yang positif yang memiliki kategori tinggi. Pernyataan-pernyataan yang menggambarkan hubungan interpersonal yang kuat dan stabil serta interkasi yang positif terlihat pada item nomor 5, 6, 7 dan 8 pada kuesioner yang telah di uji pada mahasiswa Prodi BKI.

\section{Valued Involvement (keteribatan yang berharga)}

Valued Involvement (keteribatan yang berharga) adalah pengalaman seseorang terkait perasaan dihargai, diperlukan atau dibutuhkan, serta perasaan diterima oleh lingkungannya. Teori yang menjelaskan tentang Valued Involvement (keteribatan yang berharga) juga dimilki oleh Abraham Maslow dengan nama teori Hierarki Kebutuhan. Pada tingkat keempat dalam hierarki Maslow adalah kebutuhan untuk penghargaan dan rasa hormat. Kebutuhan terhadap penghargaan berperan dalam memotivasi perilaku seseorang. Pada titik ini, orang-orang menjadi semakin membutuhkan rasa hormat dan penghargaan dari orang lain. Orang-orang memiliki kebutuhan untuk mencapai hal-hal dalam hidupnya, kemudian mereka butuh usaha tersebut diakui. Penghargaan menurut Abraham 
Maslow dikategorikan menjadi dua pada setiap individu, yaitu penghargaan terhadap diri sendiri (harga diri) dan penghargaan dari orang lain.

Harga diri adalah penilaian diri terhadap hasil yang dicapai dengan analisis, sejauh mana pencapaian tersebut memenuhi ideal diri. Sederhananya, apabila seseorang sukses dalam mencapai apa yang ingin dicapainya maka ia akan cenderung memiliki harga diri yang lebih tinggi jika dibandingkan dengan seseorang yang belum mencapai atau gagal dalam mencapai apa yang ingin dicapainya dalam hidup. Ia akan cenderung memiliki harga diri yang rendah. Harga diri ini meliputi kebutuhan akan kekuatan, kepercayaan diri, kompetensi, penguasaan terhadap suatu bidang, kecukupan, prestasi, kemandirian dan kebebasan. Semua itu dapat dicapai apabila seseorang telah memenuhi kebutuhan akan harga diri yang meliputi, menghargai diri sendiri, menghargai orang lain, dihargai orang lain, memiliki kebebasan yang mandiri dan dikenal dan diakui oleh lingkungannya. Penghargaan dari orang lain meliputi prestis, status, pengakuan, penerimaan, perhatian, kedudukan, nama baik serta ketenaran. Penghargaan ini akan sangat diperlukan dalam kehidupan bermasyarakat karena seseorang dalam suatu lingkup sosial cenderung membutuhkan penghormatan dari orang lain. Selain itu, dengan adanya penghargaan dari orang lain maka, seseorang akan menjadi lebih kreatif, mandiri, percaya diri dan juga lebih produktif.

Penghargaan yang datang dari orang lain terhadap diri kita nilainya bervariasi. Hal itu tergantung pada siapa yang memberikan penghargaan. Ini menyangkut tentang status, kedudukan, nama baik dan ketenaran yang didapatkan dari penghargaan tersebut. Apabila kita memiliki penghormatan yang tinggi terhadap seseorang yang menghargai kita, maka kita akan merasakan bahwa penghargaan darinya terasa sangat bernilai dibandingkan apabila penghargaan tersebut berasal dari orang yang tidak terlalu kita kenal, maka penghargaan yang ia berikan akan berbeda nilanya. Misalnya, ketika kita baru saja membeli baju baru dan mengenakannya pada makan malam bersama pasangan dan kemudian pasangan mengapresiasi tampilan kita yang memukau. Maka, kita akan merasa apresiasi itu sangat bernilai dibandingkan dengan apresiasi yang sama yang diberikan dari seseorang yang baru saja kita temui di tempat makan sebelum makan malam. Penghargaan keduanya akan sangat berbeda dari segi nilainya.

Hasil analisis data penelitian menunjukkan bahwa secara rata-rata keseluruhan dari indikator Valued Involvement (keteribatan yang berharga) mahasiswa Prodi BKI juga berada dalam kategori sangat tinggi. Hal ini menunjukkan bahwa Valued Involvement (keteribatan yang berharga) yang dimiliki mahasiwa Prodi BKI sangat baik.

Bukti lain yang menggambarkan bahwa mahasiswa prodi BKI memiliki Valued Involvement (keteribatan yang berharga) yang sangat tinggi adalah dengan ketika Prodi BKI menyelenggarakan kegiatan seperti BAKOMAS, Seminar Nasional dan sebagainya banyak mahasiswa yang antusias dan ikut berpartisipasi dalam 
kegiatan-kegiatan tersebut. Hal lain juga terlihat ketika Prodi BKI mengeluarkan jurnal-jurnal terbaru, banyak mahasiswa yang ikut mengklik jurnal tersebut setiap harinya dengan persentase minimal 50 orang mengklik dalam sehari. Hal ini sangat menunjang akreditasi Prodi BKI. Pernyataan-pernyataan yang menggambarkan Valued Involvement (keteribatan yang berharga) terlihat pada item nomor 9, 10, 11, 12, 13 dan 14 pada kuesioner yang telah di uji pada mahasiswa Prodi BKI.

\section{Fit (kecocokan)}

Fit (kecocokan) adalah Persepsi bahwa karakteristik yang dimiliki seseorang telah sesuai dengan sistem atau lingkungan dimana dirinya berada.teori yang berhubungan dengan fit (kecocokan) adalah teori adaptasi oleh Helson dan Wohlwill. Teori ini memiliki asumsi bahwa tingkat rangsang menengah adalah tingkat yang dapat memaksimalkan perilaku. Tingkat rangsang yang berlebihan dan tingkat rangsang yang sangat sedikit ditengarai oleh para ahli psikologi lingkungan memiliki efek merugikan terhadap keadaan emosi dan perilaku seseorang. Sementara sebagian besar ahli psikologi lingkungan menekankan kajiannya pada saling hubungan antara organisme dan lingkungan, teori tingkat adaptasi mengkaji secara spesifik pada 2 proses yang mewarnai hubungan itu, yaitu proses adaptasi (adaptation) dan penyesuaian diri (adjustment).

Dalam kehidupan, organisme melakukan mekanisme adaptasi dan penyesuaian diri pada saat menghadapi rangsang lingkungan. Adaptasi adalah perubahan respon perilaku agar sesuai dengan keadaan lingkungan, sedang penyesuaian adalah perubahan lingkungan agar sesuai dengan perilaku. Kedua proses ini akan menetukan apakah seseorang merasa cocok dengan lingkungannya atau tidak. Hasil analisis data penelitian menunjukkan bahwa secara rata-rata keseluruhan dari indikator Fit (kecocokan) mahasiswa Prodi BKI juga berada dalam kategori sedang. Hal ini menunjukkan bahwa Fit (kecocokan) yang dimiliki mahasiwa terjhadap sistem atau lingkungan Prodi BKI cukup baik. Pernyataanpernyataan yang menggambarkan Fit (kecocokan) terlihat pada item nomor 15 dan 16 pada kuesioner yang telah di uji pada mahasiswa Prodi BKI.

\section{Familiaritas dan kepercayaan}

Menurut Knight dan Chervany ada beberapa dimensi yang mendasari konsep familiaritas dan kepercayaan, diantaranya: 1) Integritas, Integritas merujuk pada kejujuran dan kebenaran. Dimensi integritas adalah yang paling penting saat seseorang menilai apakah orang lain bisa dipercaya atau tidak. 2) Kompetensi, Kompetensi meliputi pengetahuan serta keahlian teknis dan antarpersonal individu. Seseorang cenderung tidak mendengar atau menggantungkan diri pada seseorang yang kemampuannya tidak bisa dipercayai. Seseorang perlu percaya bahwa orang tersebut memiliki keahlian dan kemampuan untuk melakukan apa yang mereka katakan. 3) Konsistensi, Konsistensi berkaitan dengan keandalan, 
prediktabilitas dan penilaian yang baik pada diri seseorang dalam menangani situasi. Inkonsistensi antara kata dan perbuatan akan menurunkan tingkat kepercayaan. Konsistensi terutama relevan bagi manajer. Tidak ada hal yang paling cepat menarik perhatian melebihi ketimpangan antara kata-kata yang dikorbankan eksekutif dan apa yang mereka harapkan dilakukan oleh para rekan mereka. 4) Kesetiaan, Kesetiaan adalah kesediaan untuk melindungi dan menyelamatkan muka orang lain. Kepercayaan orang banyak bahwa seseorang mampu untuk bergantung pada seseorang yang diyakini tidak akan berlaku buruk. 5 ) Keterbukaan (Openness). Dalam batas-batas tertentu keterbukan ini memang menjadi positif dalam meneguhkan kepemimpinannya, namun ada juga hal-hal yang terkait keterbukaan ini yang mestinya dikembangkan dan dijalankan secara proporsional sesuai levelnya.

Hasil analisis data penelitian menunjukkan bahwa secara rata-rata keseluruhan dari indikator Familiaritas dan kepercayaan mahasiswa Prodi BKI juga berada dalam kategori tinggi. Hal ini berarti Familiaritas dan kepercayaan yang dimiliki mahasiwa Prodi BKI sudah baik. Dengan demikian mahasiswa Prodi BKI sudah baik dalam hal saling mempercayai satu sama lain, baik dari segi kemampuan sat sama lain maupun dari kepribadian satu sama lain. Pernyataan-pernyataan yang menggambarkan Familiaritas dan kepercayaan) terlihat pada item nomor 17, 18 dan 19 pada kuesioner yang telah di uji pada mahasiswa Prodi BKI.

Berdasarkan penjabaran yang telah dipaparkan diatas indikasi yang paling kuat dalam membuktikan tinggi rendahnya sense of belonging seseorang adalah dengan adanya perasaan mencintai, menyayangi, mau menjaga serta perduli terhadap sesuatu dalam hal ini khususnya pada Prodi BKI. Hal ini telah dijelaskan bahwa bukti yang terlihat adalah adanya motivasi yang dimilki setiap mahasiswa kemudian banyaknya mahasiswa yang mau ikut terlibat pada kegiatan Prodi BKI serta mau ikut menjaga apa yang telah disediakan.

Berdasarkan penjelasan diatas dapat disimpulkan secara keseluruhan menggambarkan bahwa teman-teman sesama mahasiswa maupaun tenaga pengajar Prodi BKI memiliki peran penting dalam meningkatkan sense of belonging seseorang. Motivasi yang mendasar, kerlibatan yang berharga, interaksi yang positif dan perasaan dihargai, adanya kecocokan serta familiaritas dan kepercayaan merupakan hal yang penting diperhatikan dalam menjaga kestabilan sense of belonging mahasiswa Prodi BKI.

\section{KESIMPULAN}

Berdasarkan skala pengukuran yang telah dibuat menggunakan 5 indikator dengan teori belongingness yang menyatakan bahwa belongingness (kepemilikan) pada seseorang adalah suatu motivasi manusia yang mendasar pada dirinya dan untuk membentuk serta mempertahankan hubungan interpersonal yang kuat dan stabil yang dibutuhkan adalah intetaksi yang sering dan tidak negatif menyatakan 
bahwa hasil penelitian menunjukkan mahasiswa Prodi BKI memiliki keberagaman dalam sense of belonging. Namun secara keseluruhan dengan nilai rata-rata yang diperoleh sebesar 68,21 menunjukkan bahwa mahasiswa Prodi BKI memiliki tingkat sense of belonging yang tinggi.

\section{DAFTAR PUSTAKA}

Baumeister, R. F., dan Kathleen, D. V. (2007). Encyclopedia of social psychology. Sage Publishing

Baumeister, Roy F., dan Mark, R. L. (1995) "The need to belong: desire for interpersonal attachments as a fundamental human motivation." Psychological bulletin (117)3.

De Moor, E. L., Johan D., dan Odilia, M. L. (2018). "Social inhibition, sense of belonging and vulnerability to internalizing problems." Journal of Affective Disorders, (225), 207-213.

Lewis, J. A., et al. (2019). "Racial microaggressions and sense of belonging at ahistorically white university." American Behavioral Scientist (65)8, 10491071.

Kurnia, M. R. (2013). Sense of belonging. Al Azhar Fresh Zone.

Museus, S. D., Yi, V., \& Saelua, N. (2017). The impact of culturally engaging campus environments on sense of belonging. Review of Higher Education: Journal of the Association for the Study of Higher Education, 40(2), 187-215.

Santrock, John W. (2003). "Adolescence perkembangan remaja." Erlangga.

Walz, L. O. (2009). The relationship between college students' use of social networkingsites and their sense of belonging. Thesis. University of Hartford.

Won, S., Wolters, C. A., dan Mueller, S. A. (2018) Sense of Belonging and SelfRegulated Learning: Testing Achievement Goals as Mediators, The Journal of Experimental Education, (86)3, 402-418.

Zhao, L., dkk. (2012). "Cultivating the sense of belonging and motivating user participation in virtual communities: A social capital perspective." International Journal of Information Management, 32(6), 574588. 